Arq. Bras. Med. Vet. Zootec., v.59, n.1, p.90-96, 2007

\title{
Ultrasonic and radiographic study of laxity in hip joints of young dogs
}

\author{
[Estudo ultra-sonográfico e radiográfico da frouxidão articular em cães jovens] \\ B.D. Rocha, R.C.S. Tôrres * \\ Escola de Veterinária da UFMG \\ Caixa Postal 567 \\ 30123-970 - Belo Horizonte, MG
}

\begin{abstract}
In the present study, 22 hip joints of Whippet (four), Rottweiler (five) and Labrador Retriever (two) young dogs were evaluated with the aim of comparing the ultrasonic examination of coxofemoral joints with the radiographic evaluations, both distraction and conventional procedures, for the early diagnosis of passive laxity. The study was based on static ultrasonography, conventional radiography (CR) and distraction radiography (DR) methods. In order to quantify the relationship between the femur head and the acetabulum, the alpha $(\alpha)$ and gamma $(\gamma)$ angles were measured by ultrasonographic examination, the Norberg angle (NA) was measured by $\mathrm{CR}$, and the distraction index (DI) was measured by DR. It was observed a negative correlation between angles $\alpha$ and $\gamma(\mathrm{r}=-0,756 ; \mathrm{P}<0.001)$ and correlation between DI and NA $(\mathrm{r}=-0.474$; $\mathrm{P}<0.026)$. No correlation was observed between angles $\alpha$ and $\gamma$ in relation to DI and NA ( $\alpha$ and DI: $r=-0.380$; $\mathrm{P}<0.081 ; \alpha$ and NA: $\mathrm{r}=0.013 ; \mathrm{P}<0.954 ; \gamma$ and DI: $\mathrm{r}=0.338 ; \mathrm{P}<0.124 ; \gamma$ and NA: $\mathrm{r}=-0.192 ; \mathrm{P}<0.391)$. The static ultrasonographic did not prove to be a sensitive method to earlier detection of passive laxity of coxofemoral joints in dogs aging 14 and 15 day-old. The distraction index of DR was efficient in early detecting the passive laxity in dogs averaging five months old, when compared to the NA of CR. Two false negative dogs were detected by the DI. The CR method was relevant to detect osteoarthritis alterations, helping the diagnosis of hip dysplasia (HD).
\end{abstract}

Keywords: dog, distraction index, hip dysplasia, Norberg angle, ultrasonography

\section{RESUMO}

Avaliaram-se 22 articulações coxofemorais de cães das raças Whippet (quatro cães), Rottweiler (cinco cães) $e$ Labrador Retriever (dois cães), com o objetivo de comparar o exame ultra-sonográfico da articulação coxofemoral de cães jovens com as avaliações radiográficas em distração e convencional, para a determinação precoce da frouxidão articular passiva. Utilizaram-se os métodos ultra-sonográfico estático, radiográfico convencional (MRC) e radiográfico em distração (MRD). Para quantificar a relação entre a cabeça do fêmur e o acetábulo, foram medidos os ângulos alfa $(\alpha)$ e gama $(\gamma)$ no exame ultra-sonográfico, o ângulo de Norberg (AN) no MRC e o indice de distração (ID) no MRD. Observou-se correlação negativa entre os ângulos $\alpha$ e $\gamma(r=-0,756 ; P<0,001)$ e entre ID e $A N(r=-0,474 ; P<0,026)$. Não se observou correlação entre os ângulos $\alpha$ e $\gamma$ em relação ao ID e o AN ( $\alpha$ e ID: $r=-0,380 ; P<0,081 ; \alpha$ e NA: $r=0,013 ; P<0,954 ; \gamma$ e ID: $r=0$, 338; $P<0,124$; ângulo $\gamma$ e AN: $r=-0,192 ; P<0,391)$. O método ultra-sonográfico estático não se mostrou sensivel para a deteç̧ão precoce da frouxidão passiva da articulação coxofemoral de cães com idade entre 14 e 15 dias. O indice de distração do MRD foi eficiente na detecção da frouxidão articular passiva em cães com idade média de cinco meses, quando comparado ao AN do MRC, sendo possível a identificação de dois cães falsos negativos. O MRC foi importante na observação das alterações osteartróticas, auxiliando o diagnóstico da displasia coxofemoral (DCF).

Palavras-chave: cão, ângulo de Norberg, displasia coxofemoral, indice de distração, ultra-sonografia

Recebido em 22 de julho de 2005

Aceito em 30 de novembro de 2006

* Autor para correspondência (corresponding author)

E-mail: rtorres@vet.ufmg.br 


\section{INTRODUCTION}

Hip dysplasia (HD) is a developmental abnormality that occurs between the femur head and the acetabulum (Tôrres, 1993). It is characterized by a genetic malformation, which inheritance model is polygenic and multifactorial (Leighton, 1997; Tôrres et al., 2001). The HD starts with joint laxity that may progress to a degenerative articular disease (DAD), with variable intensity (Smith et al., 1990; Tôrres, 2000). It is one of the most common orthopedic disorders in dogs, representing approximately $30 \%$ of the total orthopedic cases. It occurs in all breeds, however the higher prevalences are seem in middle and large size breeds, and in breeds with rapid growth (Tôrres, 2000; Rausch et al., 2004). In humans, the disease is known as hip dysplasia (HD), with $80 \%$ of the cases occurring in female children. In dogs, males and females are equally affected (Fries and Remedios, 1995; Tachdjian, 2001).

The clinical signs may vary from a discrete discomfort to voluntary paresis of the posterior members (Fry and Clark, 1992; Poy et al., 2000). Radiographycally there is incongruence between the articular surfaces, with razing of the acetabulum, flattening of the femur head, coxofemoral sub-laxity or laxity, and secondary osteoarthritis alterations. The radiographic finds are not always compatible with the clinical signs (Lust et al., 1993; Tôrres et al., 1999).

In humans as well as in dogs, the diagnosis can be done by palpation, radiographic evaluation or by ultra-sound (Fry and Clark, 1992; Adams et al., 2000). In dogs, the radiographic examination is routinely used with well defined standardization of analysis (Haan et al., 1993).

Although a lot of efforts have been made to control the disease in dogs, the prevalence of HD is still high. This fact can be attributed to several factors, but particularly to failures in the existing methods of diagnosis and control (Smith et al., 1990; Smith et al., 2002). The use of a more efficient method and an earlier detection procedure of the problem can be valuable tools to decrease the occurrence of the disease in dog populations (Adams, 2000).

In addition to the health problem of affected dogs, the HD has an important negative economical impact for dog owners, since matching of the affected dogs is not recommended and a definitive diagnosis is only achieved at 24 month-old.

An early diagnosis could constitute an important tool to control HD and will allow the clinician to adopt preventive and therapeutic measures, improving considerably the quality of life of the affected animals. Such diagnosis could also be helpful to dog owners in selecting HD free reproducer dogs reducing the economic losses in the process of raising dogs.

The objective of the present study was to compare the efficiency of the static ultrasonographic examination of coxofemoral joints of young dogs with radiographic methods (conventional and distraction) for the diagnosis of passive joint laxity.

\section{MATERIAL AND METHODS}

Four Labrador Retriever, four Whippet and five Rottweiler dogs were used in the present study. They were five females and six males aging 14 and 15-day-old (mean of 14 days). Their coxofemoral joints were evaluated by ultrasonography and from four to six month-old, the dogs were examined by radiography.

Linear transductors of high frequency (7.5 and $10 \mathrm{MHz})^{1,2}$ were used for the ultra-sound examination. The images of the dorso-lateral region of coxofemoral hips were obtained after trichotomy of the dorsal portion on the pelvic region, between the iliac crest and the ischiadic tuberosity of both articulations. After applying the acoustic gel, the transductor was placed cranium-vertically, longitudinally on the articulation, between the coxal tuber and the ischiadic tuberosity (Fig. 1), according to Greshake and Ackerman (1992).

The ultrasonographic image should contain four reference anatomical structures: the femur head (a circular, hypoechoic and heterogeneous structure), the bone of the cranium-lateral border of the acetabulum (hyperechoic surrounding), the triradiate cartilage (anechoic structure, formed by

\footnotetext{
${ }^{1}$ Medison Digital Sonoace 5500

${ }^{2}$ FF Sonic UF 4500 - Fukuba Denshi CO. Ltd
} 
the epiphysis of pubis, ileum and ischium), and the body of the ileum bone, which is a strong hyperechoic line located cranially to the cranium-lateral border of the acetabulum (Fig. 2).

The ultrasonographic examination was based on the method described by Graf (1987) for newborn children. A baseline was delineated parallel to the ileum wing, passing through the center of ossification of the femur head; a second line was delineated from the cranium-lateral border of the acetabulum to the triradiate cartilage, forming an angle with the baseline, named $\alpha$ angle. A third line was delineated passing by the cranium-lateral border of the acetabulum, touching the surrounding of the femur head, to form another angle with the baseline, named $\gamma$ angle, which allowed the evaluation of the relationship between the femur head and the acetabulum (Fig. 3). The $\beta$ angle, as measured in children, was not determined due to the fact that the ultrasonographic examination does not allow the detection of the fibrocartilaginous lip of the acetabulum in dogs.

For the conventional radiographic method (CRM), $30 \times 40 \mathrm{~cm}$ radiographic films ${ }^{3}$ were used. The animals were placed in dorsal decubit, with the posterior members extended, internally rotated, with the patel overlaying the sagital plan of the femur, the femurs parallel between them and in relation to the vertebral column and the pelvis (Tôrres and Silva, 2001). The second radiographic image, the distraction radiographic method (DRM), was obtained with $24 \times 30 \mathrm{~cm}$ radiographic films, with the animals being placed in dorsal decubit, with posterior members in neutral position (between $10^{\circ}$ flexion and $30^{\circ}$ extension, $10^{\circ}$ and $30^{\circ}$ abduction and $0^{\circ}$ and $10^{\circ}$ external rotation), the knees forming an angle of $90^{\circ}$ between the femur and the tibia/fibula. The articular distractor, model EV-UFMG ${ }^{\circledR 4}$, was adjusted between the posterior members and its bars placed on the internal face of the legs, close to the pelvis. The femurs were abducted to force the femur heads coming out from the respective acetabula.

The kilovoltage used for the radiographic images ranged from 72 to $76 \mathrm{Kvp}$, at $200 \mathrm{~mA}$, with exposition time between 0.1 and 0.15 seconds,

\footnotetext{
${ }^{3}$ Kodak MXG/Plus Medical X-Ray film - Brazilian Kodak Com. Ltd.

${ }^{4}$ Articular Distractor EV-UFMG ${ }^{\circledR}$.
}

depending on the size of the animal. The apparatus was placed at $100 \mathrm{~cm}$ from the film focus.

In order to evaluate the relationship between the femur head and the acetabulum in the radiographic images, the Norberg angle was measured using a proper scale. The quantitative and qualitative analyses in the CRM were carried out according the classification proposed by Brass et al. (1978). With regard to the DRM, the distraction index (DI) was calculated according to Smith et al. (1990).

For the ultrasonographic examination, the puppies were manually hold. For the radiographic examination the animals received $0.044 \mathrm{mg} / \mathrm{kg}$ atropine sulphate, subcutaneously; 10 minutes later $(0.5 \mathrm{mg} / \mathrm{kg}) \quad$ xylazine chlorhydrate intramuscularly, and 10 minutes later $(0.5 \mathrm{mg} / \mathrm{kg})$ diazepam intravenously.

The correlation between the variables was estimated by the method of Spearman for variables using different measuring units, and the method of Pearson for variables using the same measuring units.

\section{RESULTS AND DISCUSSION}

The ultrasonographic image taken at the age of 14 days allowed the observation of detailed anatomic features, with easy manipulation of puppies. Greshake and Ackerman (1992) reported the visualization of the actabulum without the interference of ossification of the femur head in 6week old animals. However, in the present study it was not possible to visualize the entire triradiate cartilage after 15-day-old, due to the acoustic shadow produced by the ossification center of the femur head. The femur head was predominantly hypoechoic, presenting a small hyperechoic central area, which corresponded to the ossification center. The body of the ileum was visualized as a strongly hyperechoic line, initiating in the acetabular cavity, going cranially. The cranium-lateral border of the acetabulum was seen as a hyperechoic surrounding. The articular space was visualized as an anechoic zone surrounding the femur head, and the triradiate cartilage as a hyperechoic area in the epiphyses of the rip bones. The gluteus muscles and the articular capsule were located as structures of mixed echogenicity, adjacent to the femur head. 


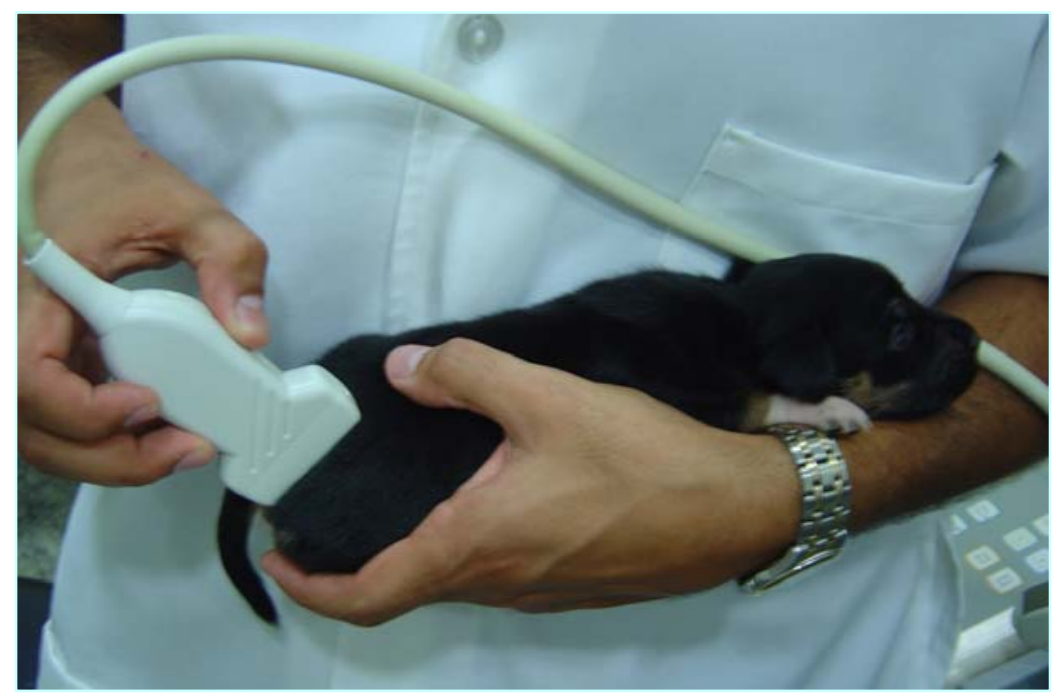

Figure 1. Transducer position for a dorso-lateral ultrasonographic image of a coxofemoral joint of a 15day-old Rottweiler puppy.

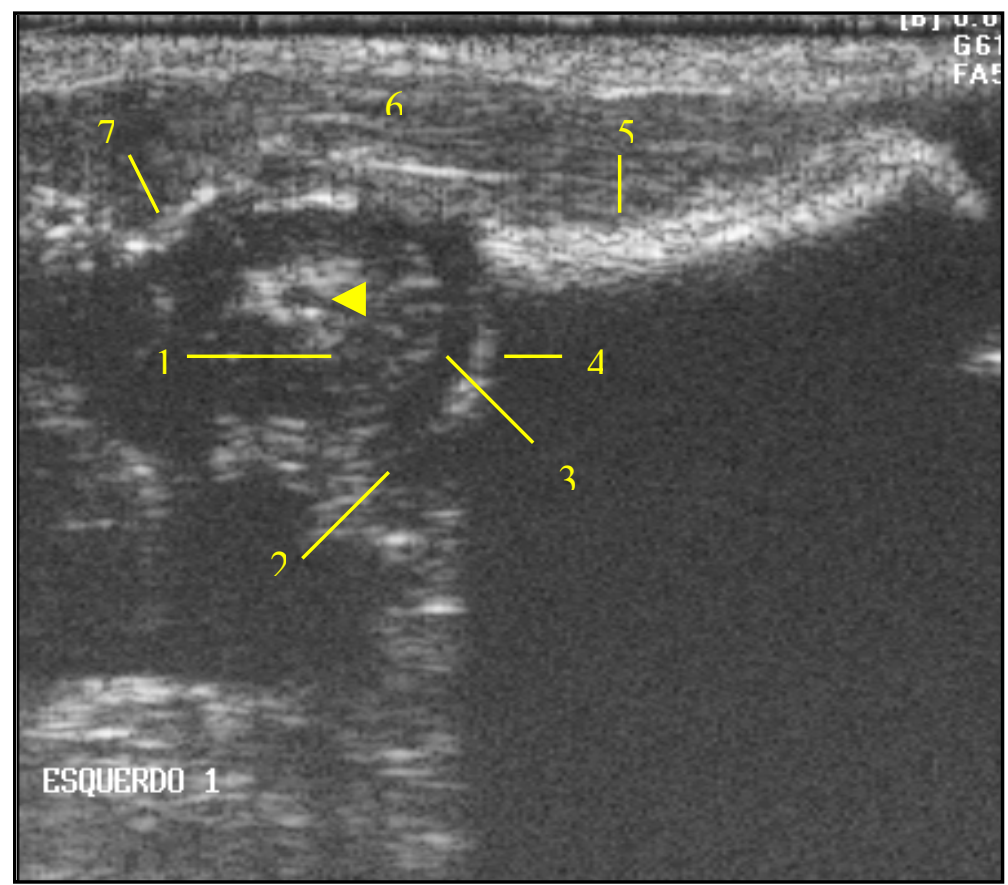

Figure 2. Ultrasonographic image of the dorso-lateral coxofemoral articulation of a 15-day-old dog. The arrow indicates the ossification center of the femur head, (1) femur head, (2) triradiate cartilage region, (3) articular space, (4) cranium-lateral border of the acetabulum, (5) ileum bone, (6) gluteus muscles and (7) articular capsule. 


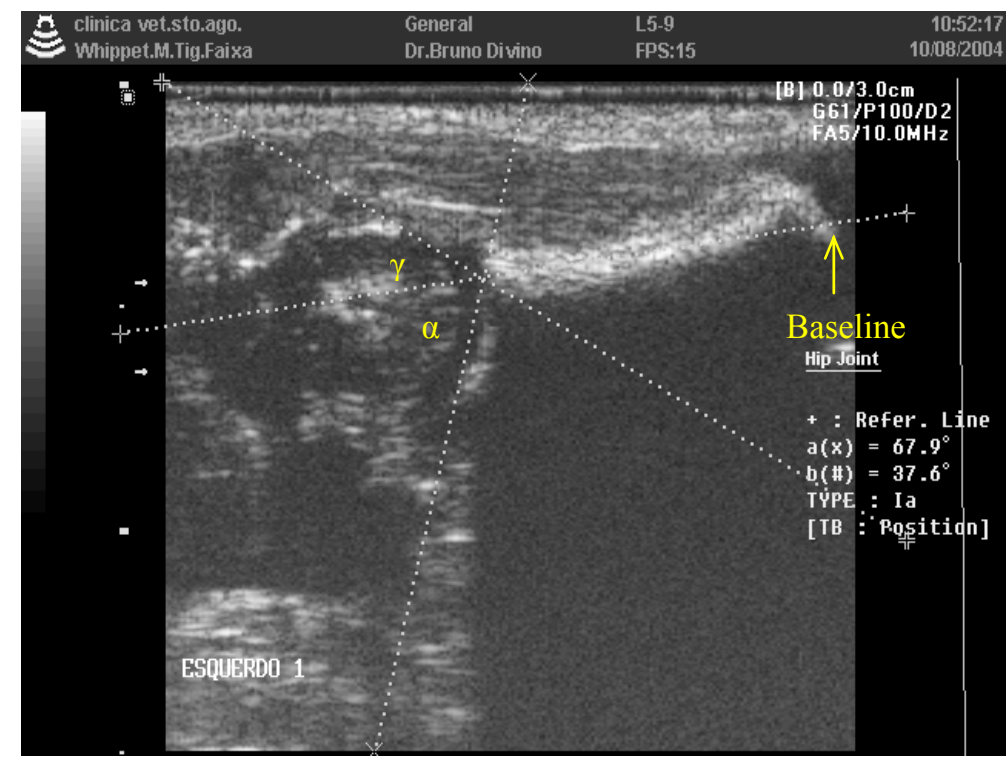

Figure 3. Ultrasonographic image corresponding to a dorso-lateral placement of the coxofemoral articulation of a 15-day-old dog, showing $\alpha$ and $\gamma$ angles.

With regard to the quantitative analysis of the ultrasonographic examination, it was observed that the bigger the $\alpha$ angle, the deeper was the acetabulum and the smaller was the $\gamma$ angle (Graf, 1987; Lima and Tavares 2002) with the femur head, confirmed by the significant negative correlation between the $\alpha$ and $\gamma$ angles $(\mathrm{r}=-0.756 ; \mathrm{P}<0.001)$ (Table 1).

The $\alpha$ angle allows to evaluate only the deep of the acetabular cavity (Graf, 1987), while the DI and the NA allow to evaluate quantitatively the relationship between the femur head and the acetabulum (Smith et al., 1990; Tôrres, 2003). No significant correlation was observed between the $\alpha$ angle and the DI $(\mathrm{r}=-0.380 ; \mathrm{P}<0.081)$ nor between the $\alpha$ angle and the NA $(r=0.013$; $\mathrm{P}<0.954$ ) (Table 1). Therefore, the DI and the NA showed to be more efficient for the proposal of the study, i.e. the evaluation of the intensity of early articular laxitiy.

Table 1. Correlations between mean values of NA, DI, $\alpha$ and $\gamma$ angles of coxofemoral articulations of 11 dogs: Whippet (four), Rottweiler (five) and Labrador Retriever (two)

\begin{tabular}{lcccccccc}
\hline & \multicolumn{2}{c}{ NA } & \multicolumn{2}{c}{ DI } & \multicolumn{2}{c}{$\alpha$ angle } & \multicolumn{2}{c}{$\gamma$ angle } \\
\cline { 2 - 8 } & $\mathrm{R}$ & $\mathrm{P}$ value & $\mathrm{R}$ & $\mathrm{P}$ value & $\mathrm{R}$ & $\mathrm{P}$ value & $\mathrm{R}$ & $\mathrm{P}$ value \\
\hline NA & 1.000 & & $-0.474^{*}$ & 0.000 & -0.013 & 0.954 & -0.192 & 0.391 \\
DI & $-0.474^{*}$ & 0.000 & 1.000 & & -0.380 & 0.081 & 0.338 & 0.124 \\
$\alpha$ angle & -0.013 & 0.954 & -0.380 & 0.081 & 1.000 & & $-0.756^{* *}$ & 0.000 \\
$\gamma$ angle & -0.192 & 0.391 & 0.338 & 0.124 & $-0.756^{* *}$ & 0.000 & 1.000 & \\
\hline
\end{tabular}

Significant correlation $(\mathrm{P}<0.05) ;{ }^{* *}$ Significant correlation $(\mathrm{P}<0.01)$.

$\mathrm{NA}=$ Norberg angle; $\mathrm{DI}=$ distraction index

According to Smith et al. (1990) and Tôrres (2003), the DI and the NA give an estimated position of the femur head in relation to the acetabulum, as well as to the $\gamma$ angle. The nonsignificant correlations between these variables $(\gamma$ angle and DI: $r=0.338 ; \mathrm{P}<0.124)(\gamma$ angle and NA: $r=-0.192 ; \mathrm{P}<0.391)$ showed that the static ultra-sonographic evaluation is not sensitive in demonstrating a passive articular laxity in 14day-old dogs. Even with the apparent normal anatomic conformation, there is a possibility of occurrence of laxity, which is not visualized through an ultra-sonographic examination, unless the femur head is forced to come out of the acetabulum. Therefore, there is a need for a 
dynamic ultra-sonographic evaluation, which was not carried out in this experiment.

The articular laxity quantified by the NA and the $\mathrm{DI}$ is considered an initial sign of HD, being an important factor to predict its diagnosis. The results indicated a significant correlation between the DI and the NA $(r=-0.474 ; \mathrm{P}<0.026)$ (Table. 1), with values similar to those obtained by Smith et al. (1990), Lust et al. (1993) and Tôrres (2003). Through the DRM, the diagnosis of passive articular laxity was possible at fivemonth-old, which was the same age observed by Lust et al. (1993) and Tôrres (2003). Biomechanical tests have demonstrated the occurrence of torsion of the articular capsule when positioning the animal for the CRM, forcing the femur head to enter into the articular capsule. This masks a passive or a functional articular laxity. According to Smith et al. (1993) and Tôrres (2003), the stress of manipulation during the DRM examination dislocates the femur head from the acetabulum when articular laxity is present, making the DRM more efficient than the CRM.
According to results reported by Smith et al. (1990) and Tôrres (2003), animals showing DI up to 0.30 are less susceptible to develop HD. In the present experiment, this aspect was also confirmed, since Whippet puppies, a breed with low susceptibility to HD, and the puppy number 6, a Ladrador Retriever, presented DI above 0.30 , all of them with NA equal or higher than $105^{\circ}$, considered normal by the CRM. However, two Rottweiler dogs ( ${ }^{\circ} 9$ and 11), also considered normal by the CRM, presented DI superior to 0.30 . These results demonstrate that the dogs had lax articulations and that the DRM allows the identification of so-called false negative dogs (Table 2). This condition has been also reported by Adams et al. (2000) and Tôrres (2003).

The qualitative evaluation of articulation is important in the search for osteoarthritis alterations, considering that this analysis, as a question of positioning, can only be properly performed within the CRM. Thus, the two methods are complementary and their association result in a more efficient diagnosis, as observed by Smith et al. (1990) and Tôrres (2003).

Table 2. Distribution of values of $\alpha$ and $\gamma$ angles, DI and NA, and qualitative evaluation of coxofemoral articulations of dogs

\begin{tabular}{|c|c|c|c|c|c|c|c|}
\hline & Breed & Member & $\alpha$ angle & $\gamma$ angle & DI & NA & Osteoarthritis alterations \\
\hline \multirow{2}{*}{1} & \multirow{2}{*}{ Whippet } & $\mathrm{L}$ & 68.4 & 49.6 & 0.20 & 105 & \multirow{2}{*}{ Absent } \\
\hline & & $\mathrm{R}$ & 68.3 & 37.7 & 0.20 & 106 & \\
\hline \multirow{2}{*}{2} & \multirow{2}{*}{ Whippet } & $\mathrm{L}$ & 64.3 & 49.0 & 0.00 & 107 & \multirow{2}{*}{ Absent } \\
\hline & & $\mathrm{R}$ & 63.0 & 45.2 & 0.25 & 105 & \\
\hline \multirow{2}{*}{3} & \multirow{2}{*}{ Whippet } & $\mathrm{L}$ & 66.4 & 40.2 & 0.00 & 113 & \multirow{2}{*}{ Absent } \\
\hline & & $\mathrm{R}$ & 68.9 & 41.2 & 0.00 & 109 & \\
\hline \multirow{2}{*}{4} & \multirow{2}{*}{ Whippet } & $\mathrm{L}$ & 70.0 & 39.5 & 0.00 & 106 & \multirow{2}{*}{ Absent } \\
\hline & & $\mathrm{R}$ & 74.2 & 42.1 & 0.00 & 105 & \\
\hline \multirow{2}{*}{5} & \multirow{2}{*}{ Labrador } & $\mathrm{L}$ & 62.2 & 54.2 & 0.50 & 97 & \multirow{2}{*}{ Present } \\
\hline & & $\mathrm{R}$ & 65.1 & 46.1 & 0.50 & 102 & \\
\hline \multirow{2}{*}{6} & \multirow{2}{*}{ Labrador } & $\mathrm{L}$ & 62.0 & 58.0 & 0.27 & 111 & \multirow{2}{*}{ Absent } \\
\hline & & $\mathrm{R}$ & 62.0 & 54.0 & 0.30 & 110 & \\
\hline \multirow{2}{*}{7} & \multirow{2}{*}{ Rottweiler } & $\mathrm{L}$ & 69.7 & 37.9 & 0.50 & 89 & \multirow{2}{*}{ Present } \\
\hline & & $\mathrm{R}$ & 62.6 & 52.1 & 0.50 & 87 & \\
\hline \multirow{2}{*}{8} & \multirow{2}{*}{ Rottweiler } & $\mathrm{L}$ & 68.9 & 49.8 & 0.42 & 98 & \multirow{2}{*}{ Present } \\
\hline & & $\mathrm{R}$ & 65.3 & 41.7 & 0.46 & 102 & \\
\hline \multirow{2}{*}{9} & \multirow{2}{*}{ Rottweiler } & $\mathrm{L}$ & 65.8 & 48.2 & 0.50 & 107 & \multirow{2}{*}{ Present } \\
\hline & & $\mathrm{R}$ & 66.0 & 47.3 & 0.60 & 105 & \\
\hline \multirow{2}{*}{10} & \multirow{2}{*}{ Rottweiler } & L & 62.6 & 48.3 & 0.56 & 99 & \multirow{2}{*}{ Absent } \\
\hline & & $\mathrm{R}$ & 63.1 & 51.9 & 0.40 & 99 & \\
\hline \multirow{2}{*}{11} & \multirow{2}{*}{ Rottweiler } & $\mathrm{L}$ & 64.1 & 46.0 & 0.50 & 110 & \multirow{2}{*}{ Present } \\
\hline & & $\mathrm{R}$ & 66.6 & 39.1 & 0.40 & 108 & \\
\hline
\end{tabular}

$\mathrm{NA}=$ Norberg angle; $\mathrm{DI}=$ distraction index; $\mathrm{L}=$ left; $\mathrm{R}=$ right. 


\section{CONCLUSIONS}

The ultrasonic examination of hip joints of 14day-old dog, allows the visualization of anatomic articular structures and could be used to evaluate joint morphological alterations. The exam is not sensitive, and in early detection of passive laxity of dogs coxofemoral hips it should not replace the distraction radiographic and the conventional radiographic methods. The distraction radiographic method is more efficient in detecting passive articular laxity when compared to the conventional radiographic method, which is more efficient in evaluating osteoarthritis alterations in young dogs.

\section{REFERENCES}

ADAMS, W.M.; DUELAND, R.T.; DANIELS, R. et al. Comparison of two palpation, four radiographic and three ultrasound methods for early detection of mild to moderate canine hip dysplasia. Vet. Rad. Ultras., v.41, p.484-490, 2000.

ADAMS, W.M. Radiographic diagnosis of hip dysplasia in the young dog. Vet. Clinc. N. Am.: Small Anim. Pract., v.30, p.267-280, 2000.

BRASS, W.; FREUDIGER, U.; MULLER, L.F. et al Bericht der hüfpelenkdysplasie-kommission. Kleintier Praxis, v.23, p.169-180, 1978.

FRIES, C.L.; REMEDIOS, A.M. The pathogenesis and diagnosis of canine hip dysplasia: a review. Can. Vet. J., v.36, p.494-501. 1995.

FRY, T.R.; CLARK, D.M. Canine hip dysplasia: clinical signs and physical diagnosis. Vet. Clinc. N. Am. Anim.: Small An. Pract., v.22, p.551-558, 1992.

GRAF, R. Guide to sonography of the infant hip. New York: Georg Thieme Verlag, 1987. 115p.

GRESHAKE， R.J.; ACKERMAN, N. Ultrasound evaluation of the coxofemoral joints of the canine neonate. Vet. Ultras., v.33, p.99-104, 1992.

HAAN, J.J.; VÉALE, B.S.; PARKER, R.B. Diagnosis and treatment of canine hip dysplasia. Can. Pract., v.18, p.24-28, 1993.

LEIGHTON, E.A. Genetics of canine hip dysplasia. $J$. Am. Vet. Med. Assoc., v.210, p.1474-1479, 1997.

LIMA, C.L.A.; TAVARES, E.C. Doença displásica do quadril. In: TAVARES, E.C., ALVES FILHO, N.; TRINDADE, O. Clínica de perinatologia - imagenologia em perinatologia, v.2, p.335-345, 2002.
LUST, G.; WILLIAMS, A.J.; BURTON-WURSTER, N. et al. Joint laxity and its association with hip dysplasia in Labrador Retievers. Am. J. Vet. Res., v.54, p.1990-1999, 1993.

POY, N.S.J.; DECAMP, C.E.; BENNETT, R.L. et al. Additional kinematic variables to describe differences in the trot between clinically normal dogs and dogs with hip dysplasia. Am. J. Vet. Res., v.61, p.974-978, 2000.

RAUSCH, S.F.; MENDES, T.C.; CARAPETO, L.P. Displasia coxofemoral felina - relato de caso. Hora Vet., v.23, p.56-57, 2004.

SMITH, G.K.; BIERY, D.N.; GREGOR, T.P. New concepts of coxofemoral joint stability and the development of a clinical stress-radiographic method for quantitating hip joint laxity in the dog. $J . A m$. Vet. Med. Assoc., v.196, p.59-70, 1990.

SMITH, G.K.; GREGOR, T.P.; RHODES, W.H. et al. Coxofemoral joint laxity from distraction radiography and its contemporaneous and prospective correlation with laxity, subjective score, and evidence of degenerative joint disease from conventional hip-extended radiography in dogs. Am. J. Vet. Res., v.54, p.1021-1042, 1993.

SMITH, G.K.; BIERY, D.M.; KEALY, R.D. et al. Significado clínico dos achados sobre osteoartrite e displasia coxofemoral no ensaio de restrição alimentar. Inf. Téc. Nestlé Purina, n.5, p.23-24, 2002.

TACHDJIAN, M.O. Ortopedia pediátrica: diagnóstico e tratamento. Rio de Janeiro: Revinter, 2001. p.168-190.

TÔRRES, R.C.S. Displasia coxofemoral em cães - parte I etiopatogenia. Rev. $C F M V$, v.7, p.38-41, 2000.

TÔRRES, R.C.S. Prevalência da displasia coxofemoral em cães da raça Pastor Alemão. 1993. 80f. (Mestrado em Medicina Veterinária) - Escola de Veterinária, Universidade Federal de Minas Gerais, Belo Horizonte.

TÔRRES, R.C.S. Uso do distrator articular no diagnóstico radiográfico precoce $d a$ displasia coxofemoral em cães. 2003. 70f. (Doutorado em Ciência Animal) - Escola de Veterinária, Universidade Federal de Minas Gerais, Belo Horizonte.

TÔRRES, R.C.S.; FERREIRA, P.M.; SILVA, D.C. Freqüência e assimetria da displasia coxofemoral em cães Pastor-Alemão. Arq. Bras. Med. Vet. Zootec., v.51, p.153156, $1999 \mathrm{~b}$.

TÔRRES， R.C.S; ROCHA， B.D.; SILVA， E.F. Freqüência da displasia coxofemoral em cães da raça Labrador Retriever no Estado de Minas Gerais. Arq. Bras. Med. Vet. Zootec., v.5, p.445-446, 2001.

TÔRRES, R.C.S; SILVA, E.F. Displasia coxofemoral em cães - parte II avaliação radiográfica. Rev. $C F M V$, v.8, p.36-40, 2001 